\title{
New Constraints from Pb-Evaporation Zircon Ages of the Méiganga Amphibole-Biotite Gneiss, Central Cameroon, on Proterozoic Crustal Evolution
}

\author{
Ganwa Alembert Alexandre $^{1 *}$, Siebel Wolfgang ${ }^{2}$, Shang Kongnyuy Cosmas ${ }^{2}$, Naimou Seguem ${ }^{1}$, \\ Ekodeck Georges Emmanuel $^{3}$ \\ ${ }^{1}$ Department of Earth Sciences, Faculty of Sciences, University of Ngaoundere, Ngaoundere, Cameroon \\ ${ }^{2}$ Department of Geosciences, University of Tübingen, Tübingen, Germany \\ ${ }^{3}$ Department of Earth Sciences, Faculty of Sciences, University of Yaounde I, Yaounde, Cameroon \\ E-mail: ganwa1@yahoo.fr \\ Received January 24, 2011; revised March 7, 2011; accepted April 19, 2011
}

\begin{abstract}
The amphibole biotite gneiss (ABGn) in the Méiganga area forms part of a meta volcano-sedimentary sequence of the Adamawa Yade domain (AYD), Central African Fold Belt (CAFB). This sequence shows affinity with immature sediments (greywackes, arkoses) with intercalation of mafic lavas or tuffs. New ${ }^{207} \mathrm{~Pb} /{ }^{206} \mathrm{~Pb}$ zircon evaporation ages for two ABGn samples range from 1887 - $2339 \mathrm{Ma}$ and from $675-889 \mathrm{Ma}$, respectively. These ages and evidence from internal zircon structures indicate that igneous rocks of Archean to Paleoproterozoic and of early Neoproterozoic age contributed to the detritus of the sedimentary sequence. The deposition of detritus took place prior to 614 - 619 Ma which represent the syntectonic emplacement of the Méiganga metadiorite. Leucogranites north to the Méiganga area were generated by melting of crust identical to that which provided the source of the ABGn. The metasedimentary sequence investigated in this study is similar to that of the southern part of the AYD and in the Borborema Province, NE Brazil. The tectonic and geochronologic characteristics of the AYD in the Méiganga area support the idea that during the Proterozoic, Central Africa and NE Brazil were part of the same continental landmass.
\end{abstract}

Keywords: Metasediment, ${ }^{207} \mathrm{~Pb} /{ }^{206} \mathrm{~Pb}$ Ages, Crustal Evolution, Adamawa Yade Domain, Central African Fold Belt

\section{Introduction and Geological Setting}

The Adamawa - Yade Domain (AYD) is one of the three main lithostructural units of the Central African Fold Belt (CAFB), defined by [1] using petrographic, structural, and isotopic data in Cameroon and Central Africa Republic (Figure 1). These authors considered the AYD as a Paleoproterozoic basement unit that was dismembered during the Pan-African orogeny. In central Cameroon (Adamawa region), the AYD is characterized by Pan-African granitoids intruding Paleo- to Neoproterozoic gneisses which are intensively overprinted by regional-scale transcurrent shear zones [1-3]. The Bafia group to the north of Yaounde, previously considered as a basement tectonic slice overthrusting the Yaoundé Group [4], is regarded as the southern extension of the AYD in Cameroon. This interpretation is strengthened by the presence of granulite facies assemblages retrogressed during the Pan-African nappe tectonics [5]. A limited number of studies are available about the petrography, deformation history, geochemistry and geochronology of the metasedimentary sequence in the southern part of AYD [5-10]. The AYD of the CAFB has several features in common with its equivalent in NE Brazil, the Brasiliano/Pan-African Borborema Province, including 1) a central position in relation to the sur- rounding cratons [11-13], 2) a network of transcurrent shear zones, and 3) the presence of metasedimentary sequences.

This study presents new zircon evaporation ages as well as geochemical data on amphibole-biotite gneiss (ABGn) from the AYD. The data are used to constrain the protolith age of the gneiss, and add knowledge to the tectonic and geochronological evolution of the AYD in 


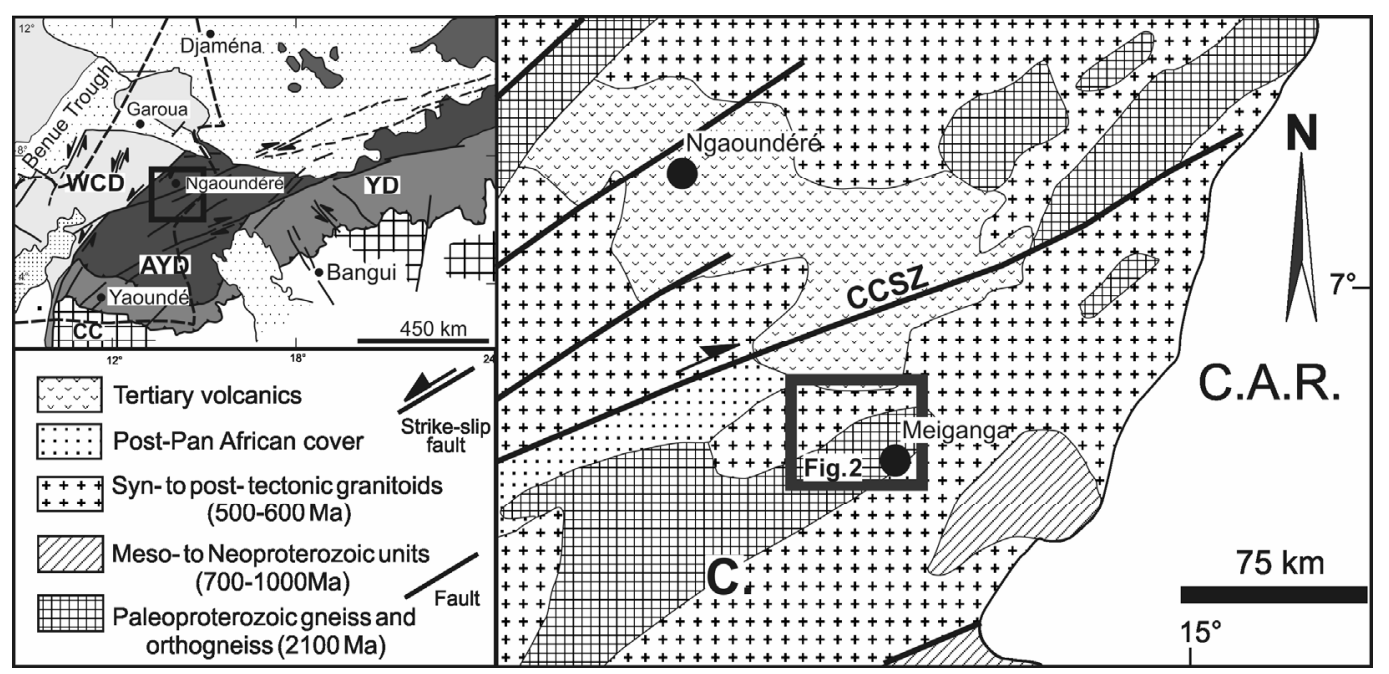

Figure 1. Geological sketch map of of the Méiganga area, East Adamawa. Inset map from [1]. Patterns are as follows: Grids, Congo Craton (CC); dark grey; Adamawa-Yadé Domain (AYD); medium grey, Yaoundé Domain (YD); light grey, West Cameroon Domain (WCD); heavy dots, Cameroon line; light dots, Mesozoic sediments. Square in inset map localizes the large figure. Cameroon (C.), Central Africa Republic (C.A.R.), Central Cameroonian Shear Zone (CCSZ).

central Cameroon during the Proterozoic and its relation to the Borborema Province.

\section{Petrography of the ABGn}

The ABGn (Figure 2) shows compositional banding marked by alternating amphibole-biotite-rich layers and quartzofeldspatic layers. It consists of green hornblende associated with brown-greenish biotite; plagioclase crystals show antiperthitic feldspar clusters, and epidote is formed at the expense of plagioclase. Accessory minerals are apatite, zircon, and titanite. The ABGn contains boudins or continuous bands ( 0.04 to $2 \mathrm{~m}$ thick) of amphibolites with nematoblatic to nematogranoblastic textures. The amphibolites are made up of green hornblende, biotite, plagioclase, quartz and opaque minerals. Accessory minerals are titanite, apatite and zircon, while secondary minerals are chlorite, epidote and calcite.

The ABGn has been affected by four deformational phases. Detailed studies on these phases can be seen in $[3,14]$.

\section{Analytical Techniques}

Major and trace elements were analysed by X-ray fluorescence (XRF) at the University of Tübingen. Rareearth elements were analysed by Inductively Coupled Plasma-Atomic Emission Spectrometry (ICP-AES) at the Centre de Recherches Pétrographiques et Géochimiques (CRPG), Vandoeuvre-lès-Nancy, France. Analytical uncertainties are estimated at $\pm 1 \%$ for major elements and $5 \%-10 \%$ for most trace elements.
Zircon grains were separated from 200-63-mm sieved rock fractions by standard separation techniques (milling, wet shaking table, magnetic and heavy liquid separation) and finally handpicked under a binocular microscope. Cathodoluminescence images were performed on an electronic microscope LEO Model 1450 VP (variable pressure) 4-Quadrant BSE-Detector working with an accelerating voltage of $10 \mathrm{kV}$. For single-zircon $\mathrm{Pb}$ evaporation, whole zircon grains were analysed using a double Re filament configuration $[15,16]$. Principles of the evaporation method are outlined in $[10,17]$.

\section{Geochemistry}

Results of geochemical analyses on selected $\mathrm{ABGn}$ samples are shown in Table 1. In the $\mathrm{MgO}-\mathrm{K}_{2} \mathrm{O}-\mathrm{Na}_{2} \mathrm{O}$ diagram (Figure 3) of de la Roche [18], the ABGn samples deviate from the magmatic trend and their chemical composition shows affinity with immature detrital sediments like greywacke and arkose whereas the amphibolites have chemical composition similar to basalt. The studied samples show variable $\left(\mathrm{Na}_{2} \mathrm{O}+\mathrm{K}_{2} \mathrm{O}+\mathrm{FeO}+\right.$ $\mathrm{MgO}+\mathrm{TiO}_{2}$ ) values ranging from 8 to 18 (Figure 4(a), [19]) and molar $\mathrm{Al}_{2} \mathrm{O}_{3} /\left(\mathrm{MgO}+\mathrm{FeO}_{\text {tot }}\right)$ values between 0.7 and 2.7 Figure 4(b), [20]. These variations may imply the heterogeneity of the protolith of the $\mathrm{ABGn}$, and are in accordance with the conclusion of [3] that the rocks of the $\mathrm{ABGn}$ belong to a metavolcanosedimentary sequence. The aluminium saturation index $\left(\mathrm{A} / \mathrm{CNK}=\left[\mathrm{Al}_{2} \mathrm{O}_{3} /(\mathrm{CaO}\right.\right.$ $+\mathrm{Na}_{2} \mathrm{O}+\mathrm{K}_{2} \mathrm{O}$ ) mol\%]) (Table 1) varies from 0.7 to 1.1 and the $\mathrm{Mg}$-number $\left[\mathrm{Mg} \#=\mathrm{Mg} /\left(\mathrm{Mg}+\mathrm{Fe}_{\text {Total }}\right)\right]$ from 0.43 to 0.50 . 


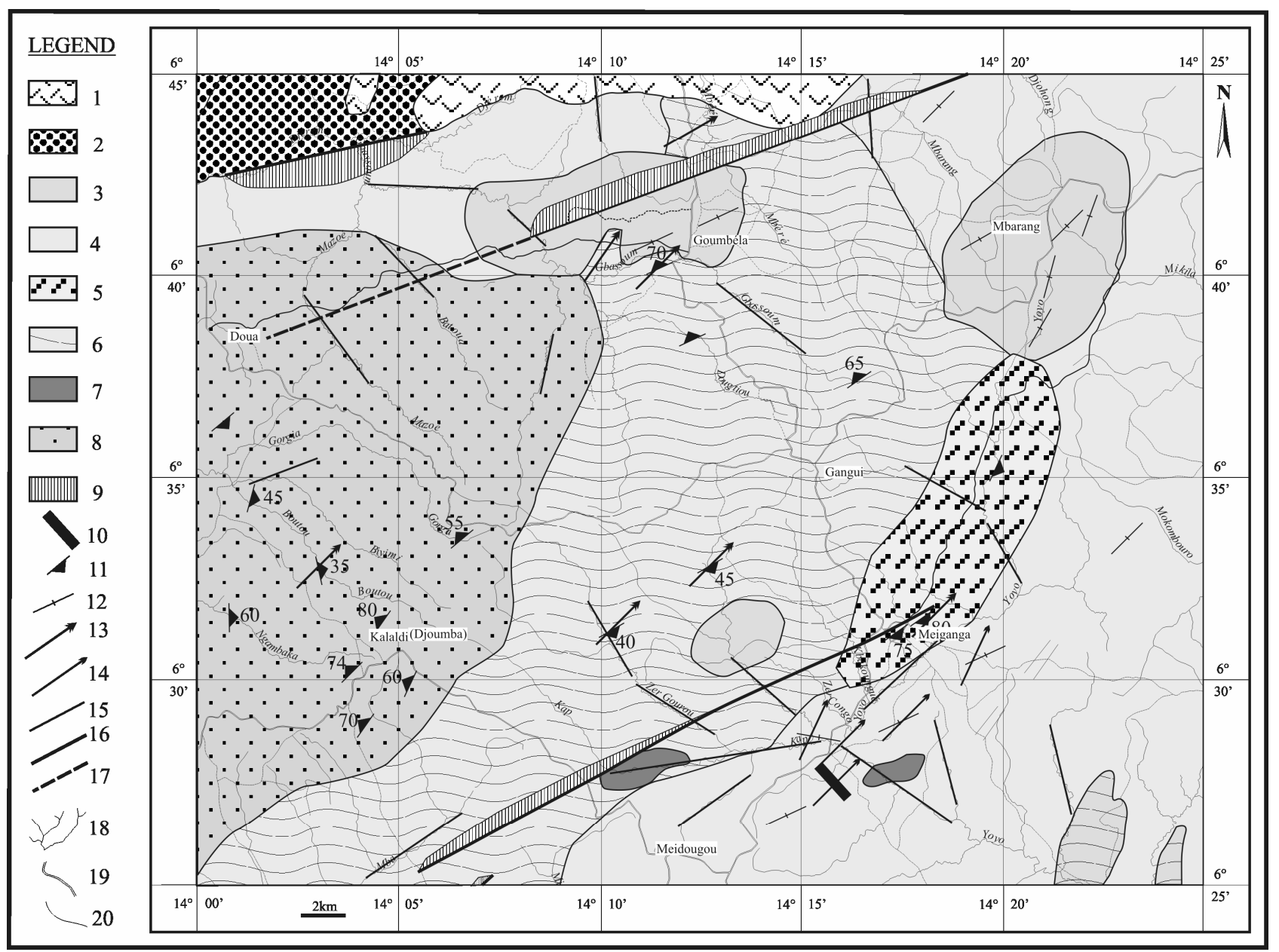

Figure 2. Geological map of Méiganga area showing the distribution of the ABGn. Legend: (1) basalt, (2) conglomerate, (3) biotite-muscovite granite, (4) pyroxene-amphibole-biotite granite, (5) banded amphibolite, (6) amphibole-biotite gneiss (ABGn), (7) amphibolite, (8) pyroxene-amphibole gneiss, (9) mylonite, (10) dolerite, (11, 12) schistosity, (13, 14) lineation, (15) fracture, (16) fault, (17) supposed fault, (18) river, (19) road, (20) path.

\section{5. ${ }^{207} \mathrm{~Pb} /{ }^{206} \mathrm{~Pb}$ Geochronology}

Representative zircon grains were studied in two samples (Me5, NY1) of the ABGn (Figure 5). Zircon grains of sample Me5 are short and oval in shape with smooth crystal faces. Grain b1 shows a high luminescence rim with truncated oscillatory zoning, surrounding a dark grey core domain. The other grains are dominated by less luminescence domains. Zircon grains from sample NY1 vary in shape. Grains b4 and b5 show dark cores surrounded by homogeneous rims with faint oscillatory zoning. This behaviour is attributed to the differential absorption of contaminants during crystallization [21] or to the effects of deformation during subsequent recrystallization [22]. Grain b3 is made up of a high luminescence rim, free of zonation, and a composite core fragment. This core is similar to the core of grain b1. Zircon grains portraying truncation of oscillatory zoning or re- gions with fading oscillatory zoning are typical of magmatic zircons modified by high-grade metamorphism [23]. Table 2 shows the analytical data obtained from evaporation of representative zircon grains of samples Me5 and NY1. In the first sample, U/Th ratios (1.2 - 2.9) decrease with increasing evaporation temperatures. The ${ }^{207} \mathrm{~Pb} /{ }^{206} \mathrm{~Pb}$ ages are Neoproterozoic, and increase with increasing evaporation temperature from $675 \pm 7$ Ma to $889 \pm 2 \mathrm{Ma}$. Sample NY1 portrays U/Th ratios of 2.0 to 5.8 , decreasing with increasing evaporation temperature. The ${ }^{207} \mathrm{~Pb} /{ }^{206} \mathrm{~Pb}$ ages of NY1 vary from $1888 \pm 2 \mathrm{Ma}$ to $2339 \pm 3$ Ma. High U/Th ratios of the two ABGn samples indicate that the zircons were derived by erosion of an igneous protoliths [24]. The ABGn was affected by the same metamorphic event as the metadiorite of the Méignanga area which was dated at $614-619 \mathrm{Ma}$ [3]. It is likely that the deposition age is therefore older than $619 \mathrm{Ma}$. The youngest age $(675 \mathrm{Ma})$ of sample Me5 
Table 1. Geochemical composition of the amphibole-biotite gneiss from the Méiganga area. (b.d.l. = below detection limit).

\begin{tabular}{|c|c|c|c|c|c|c|}
\hline Samples & NY2 & Me 5 & $\mathrm{Me} 7$ & $\mathrm{PNg} 2$ & Moo & ZBo-1 \\
\hline $\mathrm{SiO}_{2}$ & 58.25 & 61.66 & 59.41 & 74.88 & 67.88 & 63.12 \\
\hline $\mathrm{TiO}_{2}$ & 0.75 & 0.48 & 0.92 & 0.294 & 0.50 & 0.63 \\
\hline $\mathrm{Al}_{2} \mathrm{O}_{3}$ & 15.23 & 20.07 & 16.12 & 12.90 & 15.45 & 15.44 \\
\hline $\mathrm{Fe}_{2} \mathrm{O}_{3}$ & 8.54 & 3.18 & 7.23 & 2.16 & 4.24 & 6.36 \\
\hline $\mathrm{MnO}$ & 0.12 & 0.04 & 0.12 & 0.03 & 0.07 & 0.1 \\
\hline $\mathrm{MgO}$ & 3.80 & 1.20 & 3.59 & 0.76 & 1.68 & 2.81 \\
\hline $\mathrm{CaO}$ & 7.33 & 2.76 & 5.69 & 2.77 & 3.59 & 5.33 \\
\hline $\mathrm{Na}_{2} \mathrm{O}$ & 3.72 & 4.21 & 3.35 & 3.91 & 4.59 & 4.18 \\
\hline $\mathrm{K}_{2} \mathrm{O}$ & 1.75 & 6.33 & 2.59 & 1.12 & 1.80 & 1.32 \\
\hline $\mathrm{P}_{2} \mathrm{O}_{5}$ & 0.28 & 0.22 & 0.26 & 0.06 & 0.12 & 0.18 \\
\hline LOI & 0.73 & 0.75 & 0.92 & 0.38 & 0.64 & 0.67 \\
\hline Sum & 100.75 & 101.47 & 100.48 & 99.43 & 100.81 & 100.32 \\
\hline $\mathrm{Na}_{2} \mathrm{O}+\mathrm{K}_{2} \mathrm{O}$ & 6.71 & 10.54 & 5.94 & 5.02 & 6.39 & 5.50 \\
\hline $\mathrm{Na}_{2} \mathrm{O} / \mathrm{K}_{2} \mathrm{O}$ & 4.25 & 0.66 & 1.29 & 3.50 & 2.54 & 3.17 \\
\hline $\mathrm{A} / \mathrm{CNK}$ & 0.7 & 1.1 & 0.9 & 1.0 & 1.0 & 0.9 \\
\hline $\mathrm{Mg} \#$ & 0.47 & 0.43 & 0.50 & 0.41 & 0.44 & 0.47 \\
\hline $\mathrm{Ba}$ & 907.4 & 3362 & 984.3 & 730.4 & 1190.5 & 616.5 \\
\hline Co & 49.99 & 31.6 & 41.5 & 58.1 & 13 & 20.6 \\
\hline $\mathrm{Cr}$ & 92.46 & 106.6 & 164 & 93.4 & 90.6 & 51.7 \\
\hline $\mathrm{Ni}$ & 44.82 & 53 & 70.5 & 27.9 & 50.9 & 40.2 \\
\hline $\mathrm{Rb}$ & 41.6 & 114.7 & 78.9 & 18.8 & 45.7 & 24.9 \\
\hline $\mathrm{Sr}$ & 546.5 & 853.7 & 558.6 & 549.4 & 524.3 & 591.3 \\
\hline V & 143.7 & 40.98 & 146.5 & 25.5 & 63.5 & 123.7 \\
\hline $\mathrm{Y}$ & 34.44 & 5.93 & 26.8 & b.d.1. & 12.3 & 15.2 \\
\hline $\mathrm{Zn}$ & 72.41 & 56.84 & 77.6 & b.d.1. & 48.5 & 58.4 \\
\hline $\mathrm{Zr}$ & 229.2 & 534.6 & 187.3 & 184.4 & 227.5 & 148.4 \\
\hline $\mathrm{K}$ & 14543 & 52970 & 21500 & 9264 & 14967 & 10957 \\
\hline $\mathrm{La}$ & 109.2 & 54.29 & 42.7 & 30 & 63.2 & 53.9 \\
\hline $\mathrm{Ce}$ & 203.7 & 100.7 & 74.5 & b.d.l. & 102.1 & 59.5 \\
\hline $\operatorname{Pr}$ & 22.06 & 11.13 & & & & \\
\hline
\end{tabular}




\begin{tabular}{|c|c|c|c|c|c|c|}
\hline $\mathrm{Nd}$ & 78.16 & 39.92 & 38.7 & 9.7 & 34.2 & 28.8 \\
\hline $\mathrm{Sm}$ & 12.17 & 5.65 & 3.7 & b.d.l. & 6.3 & 5.1 \\
\hline $\mathrm{Eu}$ & 2.62 & 1.37 & 1.5 & 1.2 & 1.6 & 1.7 \\
\hline $\mathrm{Gd}$ & 8.70 & 3.11 & & & & \\
\hline $\mathrm{Tb}$ & 1.21 & 0.34 & & & & \\
\hline Dy & 6.53 & 1.41 & & & & \\
\hline Ho & 1.12 & 0.22 & & & & \\
\hline $\mathrm{Er}$ & 3.34 & 0.57 & & & & \\
\hline $\mathrm{Tm}$ & 0.47 & 0.08 & & & & \\
\hline $\mathrm{Yb}$ & 3.02 & 0.55 & 2.3 & 0.2 & 0.7 & 1.2 \\
\hline $\mathrm{Lu}$ & 0.45 & 0.10 & & & & \\
\hline $\mathrm{Hf}$ & 5.28 & 10.04 & & & & \\
\hline $\mathrm{Ta}$ & 0.56 & 0.32 & & & & \\
\hline W & 248.2 & 202.3 & & & & \\
\hline $\mathrm{Pb}$ & 13.79 & 38.98 & & & & \\
\hline Th & 13.38 & 9.34 & 8.4 & 3 & 14 & 1.1 \\
\hline $\mathrm{U}$ & 0.71 & 0.26 & b.d.1. & 6.4 & 4.9 & 1.7 \\
\hline $\mathrm{Nb}$ & 28.56 & 2.93 & b.d.1. & b.d.l. & b.d.1. & b.d.l. \\
\hline $\mathrm{Be}$ & 2.70 & 1.37 & & & & \\
\hline Cs & 0.36 & 1.17 & & & & \\
\hline $\mathrm{Cu}$ & 8.04 & 79.72 & & & & \\
\hline $\mathrm{Ga}$ & 21.45 & 22.02 & & & & \\
\hline $\mathrm{Ge}$ & 1.51 & 0.96 & & & & \\
\hline Mo & 1.51 & 1.24 & & & & \\
\hline $\mathrm{Sn}$ & 1.86 & 1.02 & & & & \\
\hline$\sum \mathrm{REE}$ & 487.27 & 225.38 & & & & \\
\hline $\mathrm{K} / \mathrm{Rb}$ & 373.25 & 458.33 & 272.49 & 492.76 & 327.50 & 440.05 \\
\hline $\mathrm{Rb} / \mathrm{Sr}$ & 0.04 & 0.13 & 0.14 & 0.03 & 0.09 & 0.04 \\
\hline $\mathrm{Th} / \mathrm{U}$ & 21.50 & 35.39 & & 0.47 & 2.86 & 0.65 \\
\hline $\mathrm{Sr} / \mathrm{Y}$ & 15.87 & 143.87 & 20.84 & & 42.63 & 38.90 \\
\hline $\mathrm{La}_{\mathrm{N}} / \mathrm{Yb}_{\mathrm{N}}$ & 24.55 & 67.30 & 24.55 & & & \\
\hline $\mathrm{Eu} / \mathrm{Eu}^{*}$ & 0.75 & 0.96 & 0.75 & & & \\
\hline
\end{tabular}


Table 2. Zircon evaporation data including radiogenic ${ }^{207} \mathrm{~Pb} /{ }^{206} \mathrm{~Pb}$ ratios and corresponding ${ }^{207} \mathrm{~Pb} /{ }^{206} \mathrm{~Pb}$ ages for samples $\mathrm{Me} 5$ and NY1.

\begin{tabular}{|c|c|c|c|c|c|c|c|}
\hline $\begin{array}{l}\text { Sample and zircon number } \\
\text { (a,b,c,d,e = Temp. Step) }\end{array}$ & $\begin{array}{l}\text { Evap. } \\
\text { Temp }{ }^{\circ} \mathrm{C}\end{array}$ & $\begin{array}{l}\text { No. of } \\
\text { ratios }\end{array}$ & $\mathrm{U} / \mathrm{Th}$ ratio & ${ }^{206} \mathrm{~Pb} /{ }^{208} \mathrm{~Pb}$ ratio & ${ }^{204} \mathrm{~Pb} /{ }^{206} \mathrm{~Pb}$ ratio & ${ }^{207} \mathrm{~Pb} /{ }^{206} \mathrm{~Pb}$ isotope ratio & $\begin{array}{l}{ }^{207} \mathrm{~Pb} /{ }^{206} \mathrm{~Pb} \text { age } \\
(\mathrm{Ma}) 2 \sigma \text { error }\end{array}$ \\
\hline Me5-1a & 1380 & 114 & 2.60 & 8.64 & 0.000102 & $0.064825 \pm 127$ & $768.7 \pm 4.1$ \\
\hline Me5-1b & 1400 & 114 & 1.53 & 5.00 & 0.000050 & $0.068293 \pm 106$ & $877.5 \pm 3.3$ \\
\hline Me5-1c & 1420 & 114 & 1.49 & 4.87 & 0.000041 & $0.068362 \pm 097$ & $879.6 \pm 2.9$ \\
\hline Me5-3a & 1400 & 113 & 1.57 & 5.22 & 0.000202 & $0.063386 \pm 099$ & $721.3 \pm 3.3$ \\
\hline Me5-3b & 1420 & 112 & 1.30 & 4.27 & 0.000105 & $0.066173 \pm 096$ & $811.9 \pm 3.0$ \\
\hline Me5-3c & 1440 & 112 & 1.20 & 3.94 & 0.000101 & $0.067232 \pm 108$ & $845.0 \pm 3.4$ \\
\hline Me5-4a & 1400 & 110 & 2.32 & 8.00 & 0.000249 & $0.063961 \pm 195$ & $740.4 \pm 6.5$ \\
\hline Me5-4b & 1420 & 111 & 1.27 & 4.19 & 0.000139 & $0.067693 \pm 130$ & $859.2 \pm 4.0$ \\
\hline Me5-4c & 1440 & 108 & 1.14 & 3.72 & 0.000088 & $0.068612 \pm 217$ & $887.1 \pm 6.6$ \\
\hline Me5-5a & 1400 & 114 & 1.92 & 6.26 & 0.000060 & $0.064358 \pm 132$ & $753.5 \pm 4.3$ \\
\hline Me5-5b & 1420 & 107 & 1.59 & 5.21 & 0.000060 & $0.066254 \pm 195$ & $814.4 \pm 6.2$ \\
\hline Me5-5c & 1440 & 114 & 1.35 & 4.41 & 0.000048 & $0.068689 \pm 075$ & $889.4 \pm 2.3$ \\
\hline Me5-6a & 1420 & 98 & 2.94 & 9.87 & 0.000131 & $0.062028 \pm 201$ & $675.1 \pm 7.0$ \\
\hline Me5-6b & 1440 & 109 & 1.44 & 4.72 & 0.000106 & $0.066721 \pm 196$ & $829.1 \pm 6.2$ \\
\hline NY1-1a & 1410 & 113 & 3.36 & 11.52 & 0.000042 & $0.124573 \pm 147$ & $2022.8 \pm 2.1$ \\
\hline NY1-1b & 1440 & 114 & 3.28 & 11.15 & 0.000013 & $0.130093 \pm 066$ & $2099.3 \pm 0.9$ \\
\hline NY1-1c & 1470 & 114 & 2.04 & 6.97 & 0.000013 & $0.149428 \pm 229$ & $2339.4 \pm 2.6$ \\
\hline NY1-2a & 1430 & 103 & 5.77 & 19.85 & 0.000028 & $0.121856 \pm 116$ & $1983.7 \pm 1.7$ \\
\hline NY1-2b & 1460 & 81 & 5.08 & 17.44 & 0.000028 & $0.122150 \pm 127$ & $1988.0 \pm 1.9$ \\
\hline NY1-2b & 1460 & 30 & 5.08 & 17.44 & 0.000028 & $0.123358 \pm 125$ & $2005.5 \pm 1.8$ \\
\hline NY1-4a & 1430 & 114 & 2.02 & 6.87 & 0.000028 & $0.134196 \pm 109$ & $2153.7 \pm 1.4$ \\
\hline NY1-4b & 1460 & 109 & 1.88 & 6.43 & 0.000028 & $0.143420 \pm 210$ & $2269.0 \pm 2.5$ \\
\hline NY1-4c & 1490 & 114 & 1.82 & 6.24 & 0.000028 & $0.147719 \pm 147$ & $2319.7 \pm 1.7$ \\
\hline NY1-5a & 1430 & 107 & 4.28 & 15.76 & 0.000174 & $0.115491 \pm 133$ & $1887.6 \pm 2.1$ \\
\hline NY1-5b & 1460 & 105 & 3.74 & 12.78 & 0.000030 & $0.119954 \pm 177$ & $1955.6 \pm 2.6$ \\
\hline NY1-5c & 1490 & 107 & 4.29 & 15.82 & 0.000174 & $0.120504 \pm 171$ & $1963.8 \pm 2.5$ \\
\hline
\end{tabular}

could be a post-depositional metamorphic age or a mixing age between pre-depositional and post-depositional zircon domains. It seems most likely to us, that this age post-dates the deposition of the sediments.

\section{Discussion}

\subsection{Age and Provenance of the Protolith}

Geochemical characteristics of the studied samples show that the $\mathrm{ABGn}$ comes from a sedimentary sequence whereas the protolith of the intercalated amphibolites was igneous, probably representing mafic lava, or tuff. Thus, it is likely that the whole complex represents an ancient volcano-sedimentary sequence. The ABGn shows affinity with detrital immature sediments (Figure 3), indicating that the detritus was transported only over a short distance. These sedimentary deposits were probably formed during alternate phases of volcanic activity. The zircon crystals of the ABGn show relics of magmatic structures (truncated and faint oscillatory zoning) and their $\mathrm{U} / \mathrm{Th}$ content also militates for a magmatic ori- 


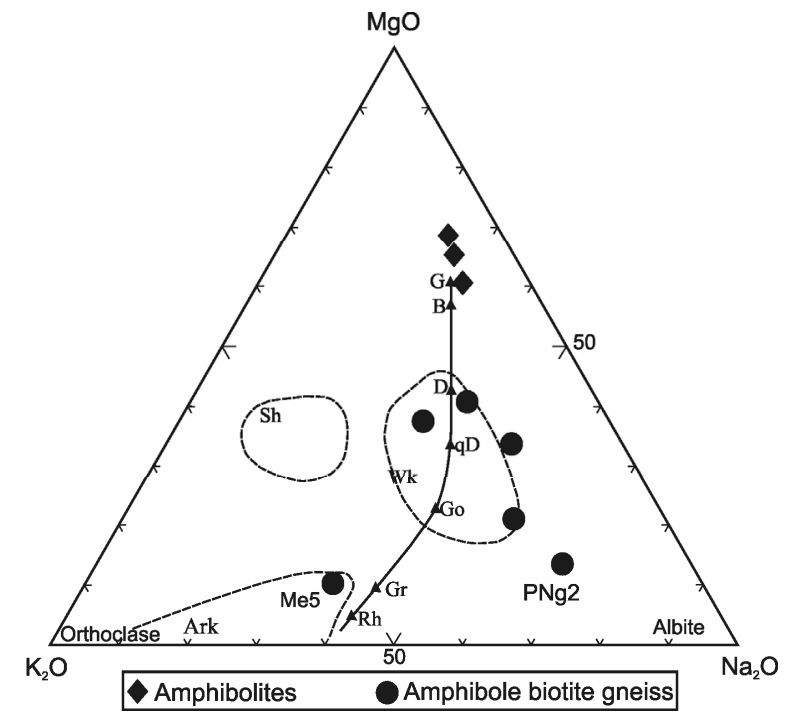

Figure 3. Geochemical characteristics of the samples from the ABGn (this study) and amphibolites [3] in the MgO$\mathrm{K}_{2} \mathrm{O}-\mathrm{Na}_{2} \mathrm{O}$ diagram [18]. Solid line shows the compositional trend of plutonic rocks with rhyolite (Rh), granite (Gr), granodiorite (Go), quartz diorite (qD), diorite (D) basalt (B), gabbro (G). Dashed contours delimit the field of shales (Sh), greywackes (WK), and arkoses (Ark).

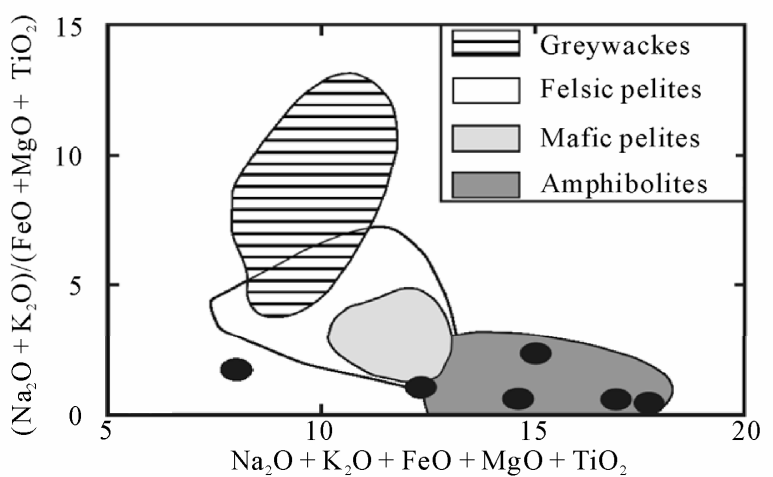

(a) gin. The ${ }^{207} \mathrm{~Pb} /{ }^{206} \mathrm{~Pb}$ zircon evaporation ages obtained for ABGn sample NY1 (1887 - $2339 \mathrm{Ma})$ fit in the range of those reported by Ganwa et al. [17] for the neighbouring pyroxene amphibole gneiss (1685-2602 Ma). The oldest age $(2339 \mathrm{Ma})$ of sample NY1 could be interpreted as a mixing age of Paleoproterozoic and Archean zircon domains; this is strengthened by the presence of dark cores in some zircon crystals (Figure 5). It seems possible that erosion of the pyroxene amphibole gneiss provided detritus for the sedimentary sequence of the ABGn. Zircon ages obtained from sample Me5 (675 - $889 \mathrm{Ma}$ ) indicate that early Neoproterozoic plutonic rocks also contributed to the detritus of the sedimentary sequence. The metasedimentary sequence of the southern AYD was derived by erosion of Mesoproterozoic (1617 Ma) to Paleoproterozoic (2289 - $2351 \mathrm{Ma})$ plutonic rocks [9,10]. Zircon grains of samples Me5 and NY1 yield ages in the same range as those of a two mica granite (sample Man and Mi, Figure 6) north of the study area [3,14]. It is likely that this Neoproterozoic leucogranite was formed by melting of the crustal material similar to the inferred protolith of the ABGn. Leucogranites generated by melting of Paleoproterozoic crustal rocks have been also described in the Serrinha-Pedro Velho Complex (Borborema Pro-

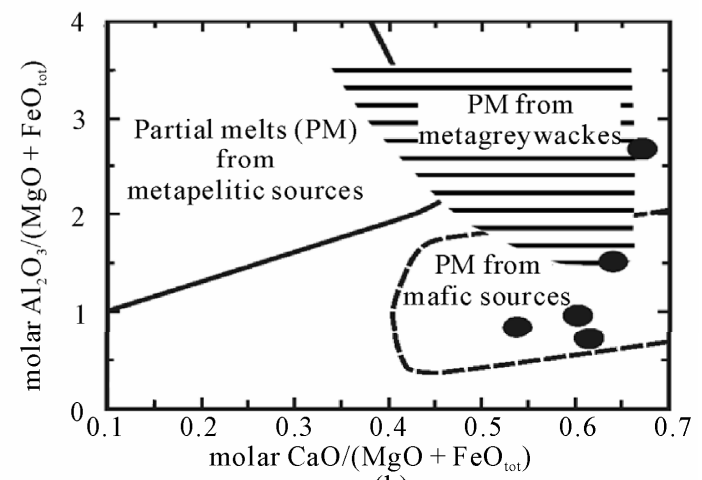

(b)

Figure 4. Geochemical characteristic of the $\mathrm{ABGn}$ in (a) the $\left(\mathrm{Na}_{2} \mathrm{O}+\mathrm{K}_{2} \mathrm{O}+\mathrm{FeO}+\mathrm{MgO}+\mathrm{TiO}_{2}\right)$ vs $\left(\left(\mathrm{Na}_{2} \mathrm{O}+\mathrm{K}_{2} \mathrm{O}\right) /\left(\mathrm{FeO}^{2}+\right.\right.$ $\left.\left.\mathrm{MgO}+\mathrm{TiO}_{2}\right)\right)[18]$ and (b) molar $\mathrm{CaO} /\left(\mathrm{MgO}+\mathrm{FeO}_{\text {tot }}\right)$ vs molar $\mathrm{Al}_{2} \mathrm{O}_{3} /\left(\mathrm{MgO}+\mathrm{FeO}_{\text {tot }}\right)$ [19] diagrams. One sample has a molar $\mathrm{CaO} /(\mathrm{MgO}+\mathrm{FeOtot})$ of 1.0 and is not shown in the diagram.

$\mathrm{Me} 5$

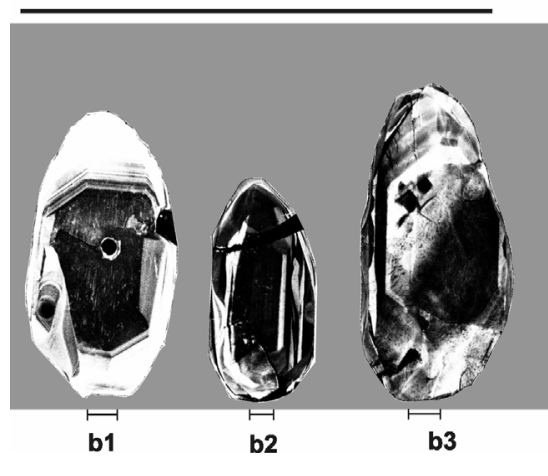

NY1

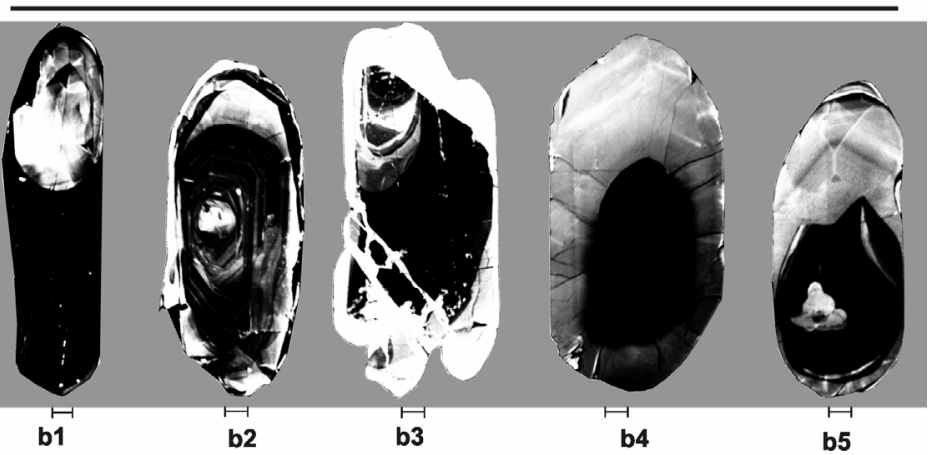

Figure 5. Cathodoluminescence images of representative zircon crystals from the ABGn. 


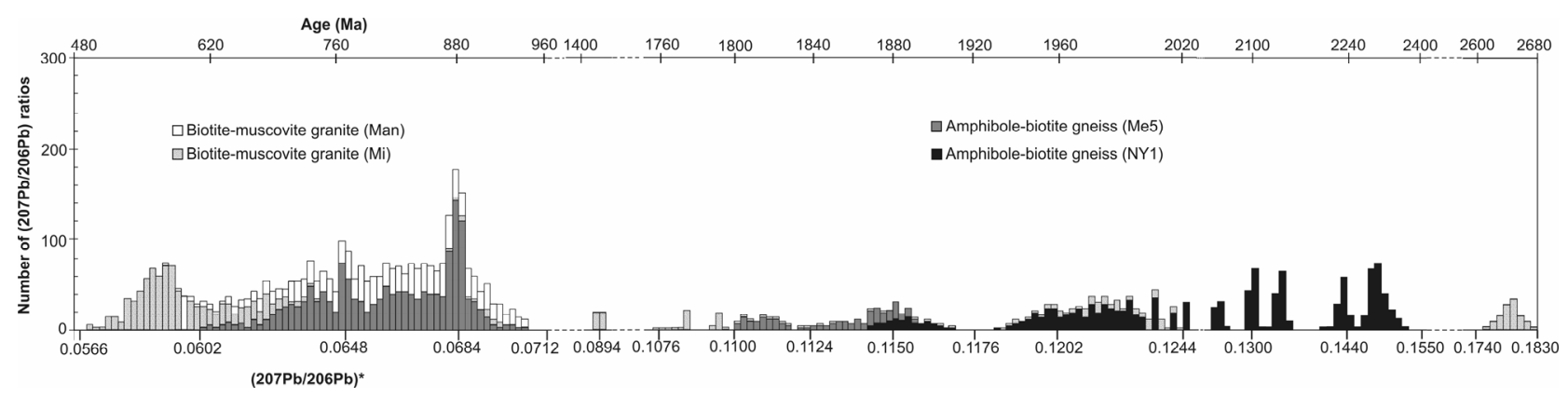

Figure 6. Histogram showing the distribution of radiogenic ${ }^{207} \mathrm{~Pb} /{ }^{206} \mathrm{~Pb}$ ratios obtained from evaporation of zircons from ABGn (samples Me5, NY1).

vince, NE Brazil; [25]).

\subsection{Deposition Age and Evolution of the ABGn}

The ABGn shows the same solid state deformation as syntectonic diorite plutons for which emplacement ages between 614 and 619 Ma were obtained [3]. It appears that the age of metamorphism in the Méiganga area is Neoproterozoic. Therefore, sedimentation must have started prior to $619 \mathrm{Ma}$ with episodes of volcanic activity. After this period, the basin and the whole region was subjected to a regional solid state transformation with four deformational phases [3]. The D1 deformational phase is present only in the ABGn whilst the D2 deformational phase, which is the major deformational phase in the AYD, is present both in the ABGn and the metadiorite.

\subsection{Comparison with the Borborema Province, NE Brazil}

A common feature between the CAFB and the Brasiliano/Pan-African Borborema province is the occurrence of metasediments outcropping in their central domain. In the Borborema province, metasediments are found in the Cachoeirinha, Alto Pajeú, Alto Moxotó and East Pernambuco belts. They consist of metapelites, metagreywackes and associated bimodal volcanic rocks, which were metamorphosed under variable conditions $[26,27]$. As for the CAFB, Neoproterozoic depositional ages (660 $620 \mathrm{Ma}$ ) were determined for the metasediments in the Borborema province $[26,27]$. Like in the AYD, the detritus of the metasedimentary sequences in the Borborema province was derived from Archean to Neoproterozoic sources. Zircon ages up to 3275 Ma have been reported for a quartzite sample from the Cachoeirinha belt [28]. Similarly, a metasedimentary complex in the AltoMoxotó belt yielded $\mathrm{Sm}-\mathrm{Nd}$ ages varying from 2.0 to $3.0 \mathrm{Ga}$ [29]. In the East Pernambuco belt, U-Pb data for detrital zircons from paragneiss exhibit ages ranging from 3320 to $665 \mathrm{Ma}$ [30].

\section{Conclusions}

Based on the present findings and relevant previous studies $[3,14,16]$, the tectonic and geochronologic evolution of the AYD in the Méiganga area can be summarized as follows: 1) $2.1-1.8 \mathrm{Ga}$ - formation of Paleoproterozoic juvenile crust, 2) 889 - $675 \mathrm{Ma}$ - generation and emplacement of early Neoproterozoic granitic melts, 3) $>619 \mathrm{Ma}$ - erosion, transportation and deposition of the detritus of the former magmatic rocks accompanied by episodes of volcanism, 4) 619 - $614 \mathrm{Ma}$ - syntectonic magmatism and metamorphism of the sedimentary sequence, 5) 601 - $558 \mathrm{Ma}$ - intrusion of late to post-tectonic granites.

The evolution summarized above is closely linked to that of the Borborema province, NE Brazil [29]. Furthermore, the existence of Archean zircon inheritances in both Central Cameroon and NE Brazil [17,29,31-35] suggests that these two regions share a similar geological history since the Paleoproterozoic.

\section{Acknowledgements}

The authors thank Dr Hartmut Schulz (University of Tübingen) for CL images. The first author is highly indebted to the German Academic Exchange Service (DAAD) for support of his research stay at University of Tübingen (Germany). Thanks go to two anonymous reviewers for their critical reviews of the manuscript.

\section{References}

[1] S. F. Toteu, J. Penaye and Y. P. Djomani, "Geodynamic Evolution of the Pan-African Belt in Central Africa with Special Reference to Cameroon," Canadian Journal of Earth Sciences, Vol. 41, No. 1, January 2004, pp. 73-85. doi:10.1139/e03-079

[2] R. Tchameni, A. Pouclet, J. Penaye, A. A. Ganwa and S. F. Toteu, "Petrography and Geochemistry of the Ngao- 
undéré Pan-African Granitoids in Central North Cameroon: Implications for Their Sources and Geological Setting," Journal of African Earth Sciences, Vol. 44, No. 4-5, April 2006, pp. 511-529. doi:10.1016/j.jafrearsci.2005.11.017

[3] A. A. Ganwa, "Les Granitoïdes de Méiganga: Etude Pétrographique, Géochimique, Structurale et Géochronologique. Leur Place Dans la Chaîne Panafricaine," Thèse d'État ès Sciences Naturelles, PH.D. Thesis, University of Yaounde 1, Yaoundé, 2005.

[4] G. Noizet, "Disposition Géologique des Régions de Yaoundé et Bafia," Annales de la Faculté des Sciences, Yaoundé, 1982.

[5] J. Tchakounté, "Etude Géologique de la Région d'Etoundou-Bayomen Dans la Série Métamorphique de Bafia: Tectonique, Géochimie, Métamorphisme," Thèse 3ème Cycle, PH.D. Thesis, University of Yaoundé I, Yaoundé, 1999.

[6] T. Ngnotué, "Pétrogenèse des Formations Métamorphiques de Ntui-Bétamba, Segment de la Chaîne Panafricaine Nord Equatoriale," Ph.D. Dissertation, University of Cocody, Abidjan, 1997.

[7] A. A. Ganwa, "Contribution à l'étude Géologique de la Région de Kombé II-Mayabo Dans la Série Panafricaine de Bafia : Géomorphologie Structurale, Tectonique, Pétrologie," Thèse de $3 e$ Cycle, PH.D. Thesis, University of Yaoundé 1, Yaounde, 1998.

[8] E. T. Njiosseu, J. Nzenti, T. Njanko, B. Kapajika and A. Nédélec, "New UPb Zircon Ages from Tonga (Cameroon): Coexisting Eburnean-Transamazonian (2.1 Ga) and Pan-African (0.6 Ga) Imprints," Comptes Rendus Geosciences, Vol. 337, No. 6, March 2005, pp. 551-562. doi:10.1016/j.crte.2005.02.005

[9] J. T. Numbem, et al., "Evidence of Ca. 1.6-Ga Detrital Zircon in the Bafia Group (Cameroon): Implication for the Chronostratigraphy of the Pan-African Belt North of the Congo Craton," Comptes Rendus Geosciences, Vol. 339, No. 2, January 2007, pp. 132-142.

[10] A. A. Ganwa, W. Frisch, W. Siebel, G. E. Ekodeck, C. K. Shang, J. M. Ondoa, M. Satir and J. T. Numbem, "Zircon ${ }^{207} \mathrm{~Pb} /{ }^{206} \mathrm{~Pb}$ Evaporation Ages of Panafrican Metasedimentary Rocks in the Kombé-II Area (Bafia Group, Cameroon): Constraints on Protolith Age and Provenance," Journal of African Earth Sciences, Vol. 51, No. 2, May 2008, pp. 77-88.

doi:10.1016/j.jafrearsci.2007.12.003

[11] R. Caby, A. N. Sial, M. H. Arthaud and A. Vauchez, "Crustal Evolution and the Brasiliano Orogeny in Northeast Brazil," In: R. D. Dallmeyer and J. P. Lécorché, Eds., The West African Orogens and Circum-Atlantic Correlatives, Springer, Berlin, 1991, pp. 373-397.

[12] C. Castaing, J. L. Feybesse, D. Thiéblemont, C. Triboulet and $\mathrm{P}$. Chèvremont, "Paleogeographical Reconstructions of the Pan-African/Brasiliano Orogen: Closure of an Oceanic Domain or Intracontinental Convergence between Major Blocks?" Precambrian Research, Vol. 69, No. 1-4, October 1994, pp. 327-344. doi:10.1016/0301-9268(94)90095-7
[13] R. Trompette, "Neoproterozoic ( 600 Ma) Aggregation of Western Gondwana: A Tentative Scenario," Precambrian Research, Vol. 82, No. 1-2, March 1997, pp. 101112. doi:10.1016/S0301-9268(96)00045-9

[14] A. A. Ganwa, W. Frisch, W. Siebel and C. K. Shang, "Geochemistry of Magmatic Rocks and Time Constraints on Deformational Phases and Shear Zone Slip in the Méiganga Area, Central Cameroon," International Geo- logy Review, Vol. 53, No. 7, 2011, pp. 759-784. doi:10.1080/00206810903211161

[15] B. Kober, "Whole Grain Evaporation for $207 \mathrm{~Pb} / 206 \mathrm{~Pb}$ -Age-Investigations on Single Zircons Using a Double-Filament Thermal Ion Source," Contribution to Mineralogy and Petrology, Vol. 93, No. 4, 1986, pp. 482-490. doi:10.1007/BF00371718

[16] B. Kober, "Single Zircon Evaporation Combined with $\mathrm{Pb}^{+}$Emitter Bedding for $207 \mathrm{~Pb} / 206 \mathrm{~Pb}$-Age Investigations Using Thermal Ion Mass Spectrometry, and Implications in Zirconology," Contribution to Mineralogy and Petrology, Vol. 96, No. 1, 1987, pp. 63-71. doi:10.1007/BF00375526

[17] A. A. Ganwa, W. Frisch, W. Siebel, G. E. Ekodeck, C. K. Shang and V. Ngako, "Archean Inheritances in the Pyroxene-Amphibole-Bearing Gneiss of the Méiganga Area (Central North Cameroon): Geochemical and ${ }^{207} \mathrm{~Pb} /{ }^{206} \mathrm{~Pb}$ Age Imprints," Comptes Rendus Geosciences, Vol. 340, No. 4, April 2008, pp. 211-222. doi:10.1016/j.crte.2007.12.009

[18] H. de la Roche, "Sur l'existence de Plusieurs Faciès Géochimiques Dans Les Schistes Paléozoïques Des Pyrénées Luchonnaises," Geologie Rundschau, Vol. 55, 1965, pp. 274-301.

[19] A. E. P. Douce, "What Do Experiments Tell Us about the Relative Contribution of Crust and Mantle to the Origin of Granitic Magmas?" In: A. Castro, C. Fernandez and J. L. Vigneresse, Eds., Understanding Granites: Integrating New and Classical Techniques, Geological Society London, London, 1999, pp. 55-75.

[20] R. Altherr, F. Henjes-Kunst, C. Langer and J. Otto, "Interaction between Crustal-Derived Felsic and Mantle-Derived Mafic Magmas in the Oberkirch Pluton (European Variscides, Schwarzwald, Germany)," Contribution to Mineralogy and Petrology, Vol. 137, No. 4, 1999 pp. 304-322

[21] G. Vavra, "On the Kinematics of Zircon Growth and Its Petrogenetic Significance: A Cathodoluminescence Study," Contribution to Mineralogy and Petrology, Vol. 106, No. 1, 1990, pp. 90-99. doi:10.1007/BF00306410

[22] R. T. Pidgeon, "Recrystallisation of Oscillatory Zoned Zircon: Some Geochronological and Petrological Implications," Contribution to Mineralogy and Petrology, Vol 110, No. 4, 1992, pp. 463-472. doi:10.1007/BF00344081

[23] F. Corfu, J. M. Hanchar, P. W. O. Hoskin and P. Kinny, "Atlas of Zircon Textures," Reviews in Mineralogy \& Geochemistry, Vol. 53, No. 1, 2003, pp. 469-500. doi: $10.2113 / 0530469$

[24] I. S. William and S. Claesson, "Isotopic Evidence for the Precambrian Provenance and Caledonian Metamorphism 
of High-Grade Paragneiss from the Seve Nappes, Scandinavian Caledonides," Contribution to Mineralogy and Petrology, Vol. 97, No. 2, 1987, pp. 205-217. doi:10.1007/BF00371240

[25] I. de P. Guimarães, et al., "Trans-Alkaline Magmatism in the Serrinha-Pedro Velho Complex, Borborema Province, NE Brazil and Its Correlations with the Magmatism in Eastern Nigeria," Gondwana Research, Vol. 15, No. 1, February 2009, pp. 98-110. doi:10.1016/j.gr.2008.06.011

[26] V. C. Medeiros, "Evolução Geodinâmica e Condicionamento Estrutural dos Terrenos Piancó-Alto Brígida e Alto Pajeù, Domínio da Zona Transversal, NE do Brasil," Ph.D. Thesis, Universidade Federal do Rio Grande do Norte, Natal, 2004.

[27] M. Kozuch, "Isotopic and Trace Element Geochemistry of Early Neoproterozoic Gneissic and Metavolcanic Rocks in the Cariris Velhos Orogen of the Borborema Province, Brazil, and Their Bearing on Tectonic Setting," Ph.D. Thesis, University of Kansas, Natal, 2003.

[28] L. C. Silva, N. J. McNaughton, A. L. Vasconcelos, J. C. R. Gomes and I. R. Fletcher, "U-Pb SHRIMP Ages in Southern State of Ceará, Borborema Province, Brazil: Archean TTG Accretion and Proterozoic Crustal Reworking," Proceedings of the 2nd International Symposium on Granites and Associated Mineralization, Salvador, 24-29 August 1997, pp. 280-281.

[29] B. B. B. Neves, M. C. C. Neto, W. R. V. Schmus, T. M. G. Fernandes and S. L. Souza, "O Terreno AltoMoxotó o no Leste da Paraíba (Maciço Calda Brabdão)," Revista Brasileira de Geosciências, Vol. 31, No. 2, 2001, pp. 185-194.

[30] S. P. Neves, O. Bruguier, A. Vauchez, D. Bosch, J. M. R. Silva and G. Mariano, "Timing of Crust Formation, Deposition of Supracrustal Sequences, and Transamazonian and Brasiliano Metamorphism in the East Pernambuco Belt (Borborema Province, NE Brazil): Implications for Western Gondwana Assembly," Precambrian Research, Vol. 149, No. 3-4, September 2006, pp. 197- 216. doi:10.1016/j.precamres.2006.06.005

[31] W. R. V. Schmus, et al., "U/Pb and $\mathrm{Sm} / \mathrm{Nd}$ Geochronologic Studies of the Eastern Borborema Province, Northeastern Brazil: Initial Conclusions," Journal of South American Earth Sciences, Vol. 8, No. 3-4, 1995, pp. $267-$ 288. doi:10.1016/0895-9811(95)00013-6

[32] O. O. Melo, I. P. Guimarães, A. Fetter and H. Beurlen, "Idades U/Pb em Zircão e Idades Modelo $(\mathrm{Sm} / \mathrm{Nd})$ de Ortognaisses e Enclaves Metamórficos da Área de BarroVermelho-PE, Terreno Alto Moxotó, Província Borborema, Nordeste do Brasil," Revista Brasileira de Geociências, Vol. 32, No. 2, 2002, pp. 197-204.

[33] V. P. Ferreira, A. N. Sial and E. F. Jardim de S'a, "Geochemical and Isotopic Signatures of Proterozoic Gra- nitoids in Terranes of the Borborema Structural Province, Northeastern Brazil," Journal of South American Earth Sciences, Vol. 11, No. 5, 1998, pp. 439-455. doi:10.1016/S0895-9811(98)00027-3

[34] G. Mariano, S. P. Neves, A. D. S. Filho and I. P. Guimarães, "Diorites of the High-K Calc-Alkalic Association: Geochemistry and Sm-Nd Data and Implications for the Evolution of the Borborema Province, Northeast Brazil," International Geology Review, Vol. 43, No. 10, 2001, pp. 921-929. doi:10.1080/00206810109465056

[35] I. P. Guimarães and B. B. B. Neves, "Geochemistry Characterization of Part of the Early Neoproterozoic plutonism in the Central Structural Domain of the Borborema Province, NE Brazil," Proceedings of the 32nd International Geological Congress, Firenze, 20-28 August 2004 